increasing by $50 \%$ during the 1980 s to an average of nearly 17 million hectares per year.

Although the above findings on global soil degradation are preliminary, the figures in Table $I$ offer the best available estimates of this serious environmental problem. The report is drawn from a three-years' Global Assessment of Soil Degradation (GLASOD) survey sponsored by the United Nations Environment Programme and coordinated by the International Soil Reference and Information Centre in The Netherlands. The data were provided by more than 250 soil scientists around the world, the survey being part of a large-scale, 15-years' global soil study.

SHIRLEY GEER
World Resources Institute
1709 New York Avenue, NW
Washington
DC 20006, USA.

\title{
St Petersburg A-Ya Society Looking for Foreign Collaborators
}

The St Petersburg A-Ya Society is organized to support environmental and other scientists and others who aspire to establish businesses of their own but need juridical and financial help and general guidance. The Society is a noncommercial but self-supporting organization of humanitarian orientation. Its most desirable task is to guide scientists and others through the hardships of the reconstruction period in Russia, in conditions of chronic destruction of the centralized state structures, to create independent, private establishments of high professional level.

At the present time the Society consists of an administrative staff ( 3 directors, 2 economists, a lawyer, and several assistants) and 80 independent private companies, realizing artistic, scientific, and technical, programmes under the Society's supervision. Among the companies are two former collective farms and a group of biologists in the geological-ecological company 'United Laboratories'.

United Laboratories is one of the companies duly organized within the structure of the A-Ya Society. It deals with geological and ecological problems (both fundamental and applied), and consists of several research groups, scientific laboratories, and individual professionals who were formerly working in such state structures as $\mathrm{St}$ Petersburg University, the Petroleum Institute, the Institute of Toxicology (Petersburg), and some geological groups in Ukhta (Timan-Pechora region), etc.
All of the specialists working for the United Laboratories are experienced professionals with Doctoral degrees. They are studying the basic problems of geology and ecology together with such specific practical tasks as geochemical mapping (of polluting elements), drug, toxic, and bioactive substances' effects, testing the influence of polluting substances on living organisms, and other special problems.

The St Petersburg A-Ya Society aims to promote international activities by establishing representative offices for foreign companies, societies, and other organizations, and is concerned about the exchange of scientific and cultural achievements in the form of exhibitions, conferences, international expeditions, concerts, etc. The Society is especially interested in active participation in international ecological programmes, and can suggest broadly-oriented specialists working in several neighbouring scientific areas (microbiology, toxicology, geochemistry, etc.). For further information please telephone Geneva (022) 346-3132 or 786-9383, or St Petersburg 2591111 , or otherwise contact the undersigned.

OLGA A. NALIV
International Pro
Kermely $12-32$
Geneva 1206
Switzerland.

Olga A. NALIVKina

Kermely 12-32

Switzerland.

\section{Solid Waste Association of North America}

The Solid Waste Association of North America (SWANA) was established as the Governmental Refuse Collection and Disposal Association (GRCDA) in 1961, primarily to assist municipal solid-waste management professionals who were working for local government, to meet their responsibilities in refuse collection and disposal.

Since that beginning, GRCDA has grown to address the entire spectrum of municipal solid-waste management, has broadened its membership to include both publicly and privately employed municipal solid-waste management professionals, has changed its name to reflect how the field has changed from refuse collection and disposal to municipal solid-waste management, and is now the largest member-based solid-waste association in the world. SWANA membership is principally from the US and Canada, but SWANA also has members in more than 10 other countries.

SWANA, in serving its membership and involved professionals, has a dual mission:

1. To serve as the centre of technical excellence in municipal solid-waste management; and
2. To represent the interests of the municipal solidwaste management professional.

To carry out this dual mission, SWANA has a number of programmes which are directed to serving the membership, nine of which are the following:

- SWANA trains over 6,000 individuals every year in all areas of municipal solid-waste management (MSWM).

- SWANA offers a number of speciality conferences and technical symposia in all aspects of MSWM.

- SWANA has the largest solid-waste library in the world.

- Through SWICH (Solid Waste Information Clearinghouse), SWANA provides electronic access as well as direct access to literature services and technical information.

- SWANA provides technical assistance and networking to assist practitioners in carrying out their responsibilities.

- SWANA conducts and supports professionalism in the field through training and certification of practitioners. 